\title{
DESIGN HYDROGRAPH ESTIMATION IN SMALL AND UNGAUGED BASINS: A COMPARATIVE ASSESSMENT OF EVENT BASED (EBA4SUB) AND CONTINUOUS (COSMO4SUB) MODELING APPROACHES
}

\author{
Andrea Petroselli ${ }^{1 \bowtie}$, Salvatore Grimaldi², Rodolfo Piscopia ${ }^{3}$, Flavia Tauro² \\ ${ }^{1}$ Department of Economics, Engineering, Society and Enterprise (DEIM), University of Tuscia, Via San Camillo De Lellis snc, \\ 01100 Viterbo, Italy \\ 2 Department for Innovation in Biological, Agro-food and Forest systems (DIBAF), University of Tuscia, Via San Camillo de Lellis snc, \\ 01100 Viterbo, Italy \\ ${ }^{3}$ Freelance, Rome, Italy
}

\begin{abstract}
Aim of the study

Aim of the study is to provide a comparative assessment of event based (EBA4SUB) and continuous (COSMO4SUB) modeling approaches for rainfall-runoff modeling for small and ungauged basins, focusing on the influence of the Antecedent Moisture Condition (AMC) of the soil on the estimated design peak discharge.

Material and methods

The event based approach is the EBA4SUB software. It consists in selecting a design rainfall event, estimating the rainfall excess, and transforming it into the direct hydrograph. The continuous approach is the COSMO4SUB framework. It consists in generating a long synthetic rainfall time series at sub-daily resolution that feeds a continuous rainfall-runoff model. Then, a discharge time series is determined, providing the estimation of the runoff and the related peak discharge.
\end{abstract}

\begin{abstract}
Results and conclusions
Results show the critical role of antecedent moisture condition (AMC) and how subjective the event-based approach is for determining the design hydrograph and peak discharge. In the event-based approach, AMC is arbitrarily selected by the analyst, while in the continuous modeling it is automatically determined using the synthetic rainfall input. Our findings indicate that the event-based approach systematically leads to a considerable overestimation of floods if AMC III (wet soil) is assumed or to a slight underestimation of floods if AMC II (average condition for soil humidity) is selected.
\end{abstract}

Keywords: Continuous modeling, COSMO4SUB, design hydrograph, EBA4SUB, event-based approach, rainfall-runoff modeling

\section{INTRODUCTION}

The design hydrograph (DH) estimation is a fundamental topic in hydrology, being required for a number of applications, from hydraulic structure designs to flood risk-mapping procedures (Directive 2007/60/
EC, 2007; FEMA, 2009). Methods for estimating DH are strongly dependent on watershed characteristics and data availability. In this contribution, we investigate the case of "small" and "ungauged" basins. For "small" we refer to basins where it is reasonable to assume a linear behavior and to apply the instanta-

凶e-mail:petro@unitus.it 
neous unit hydrograph (IUH) theory (Dooge, 1973). Small basins are usually "ungauged", i.e. without discharge observations, which are needed for calibrating advanced hydrological models. This in turn yields a critical task for the analyst. Generally, only digital elevation models (DEMs) with a standard resolution, land use / land cover digital support, soil type and rainfall data are available.

In the literature, two distinct methodologies for evaluating DH in small and ungauged basins are generally recommended: the 'event-based' scheme and the 'continuous simulation' approach. The 'event-based' scheme defines DH through the rainfall-runoff transformation of a design hyetograph that is characterized by an assigned return period (Tr) and that is usually deduced employing the Depth-Duration-Frequency (DDF) or the Intensity-Duration-Frequency (IDF) curves (Hsieh et al., 2006; Alfieri et al., 2008). The more recent 'continuous simulation' approach consists in generating a long synthetic rainfall time series, calibrated with observed data, and transforming it through a continuous rainfall-runoff model. From the obtained runoff time series, DH is derived according to the following steps. 1) A driving-variable (usually the peak discharge) is defined. 2) Flood events are analyzed, and each event is characterized by peak discharge, total volume, and total duration values. 3) Annual sieving is applied and the sampled hydrograph is selected by choosing the event with the maximum value of the driving-variable. 4) Non-dimensional hydrographs are derived from the sampled ones by dividing their bases by duration and multiplying their ordinates by duration/volume ratio. 5) Datasets of driving and non-driving variables (usually volume and duration) are put together by analyzing the sampled non-dimensional hydrographs. 6) The best-fitting statistical distribution is estimated for the driving-variable dataset. 7) The statistical relationships between driving and non-driving parameters are derived. 8) Inference on the return value of driving-parameter is carried out and the related expected values of the non-driving parameters are obtained from the settled relationships. 9) A standardized design hydrograph is defined. 10) The DH is obtained from the standardized hydrograph, which corresponds to the driving-parameter with assigned return period, by multiplying its basis by the expected duration, and its ordinates by the expected volume/ duration ratio (Moretti and Montanari, 2008; Grimaldi et al., 2012a,b).

The event-based scheme is widely applied since it is based on the easily available DDF or IDF curves but this approach involves some assumptions whose effects are difficult to quantify. The simplified shape (often rectangular) of the assumed hyetograph, the concept of critical rainfall duration (usually equal to the basin time of concentration) and the lack of information about the antecedent soil wetness condition can result in a great uncertainty (Hoes and Nelen, 2005; Verhoest et al., 2010).

In order to overcome such drawbacks, in the last few years, continuous modeling approaches have been developed and many authors have evaluated their performances with respect to event-based methods (Nnadi et al., 1999; Alfieri et al., 2008; Viglione and Bloschl, 2009; Nishat et al., 2010; Grimaldi et al., 2012b; Winter et al., 2019). The aforementioned literature focused on the comparison between the design hydrograph peak discharges, volumes, and durations obtained with both the methodologies, and this revealed that event-based approaches usually tend to underestimate the flood peaks and volumes. In particular, many authors highlighted the uncertainty in the flood inundation mapping procedure caused by the subjective selection of key parameters and by the simplification of the involved hydrological and hydraulic processes occurring in the watershed (Merwade et al., 2008; Di Baldassarre et al., 2010; Kalyanapu et al., 2012).

Literature analyses support the hypothesis that the main cause for the differences in the two methodologies is related to a combined effect of the infiltration process and the simulated rainfall pattern. For example, the realistic rainfall time pattern given by the continuous approach influences the initial losses and allows preservation of the rainfall peaks. The eventbased approaches, based on a simple representation of rainfall processes, have been the simplest and most commonly applied procedures for decades but their results are often impacted by conceptual hypotheses and assumptions. The more recent continuous approach seems to overcome some drawbacks of the eventbased approach, removing the subjective hypothesis needed to combine the rainfall and infiltration models. Literature analysis reveals that, although the continuous scheme is able to provide useful results, further 
investigations are necessary, for instance concerning infiltration modeling.

In this study, we apply both the methodologies with the aim of investigating the influence of the Antecedent Moisture Condition (AMC) on the estimated design peak discharge for a selected case study located in central Italy. In particular, we compare the design peak discharges, characterized by different return periods, obtained by two recently developed methodologies. The first scheme pertains to the event-based approach (EBA4SUB) (Grimaldi and Petroselli, 2015; Piscopia et al., 2015; Petroselli and Grimaldi, 2018), the second implements a continuous framework (COSMO4SUB) (Grimaldi et al., 2012ab). Both methodologies are characterized by state-of-the-art modules and have been designed for small and ungauged basins.

\section{MATERIALS AND METHODS}

\section{Data set}

The selected case study is the watershed of the Vezza River, a right tributary of the Tiber River, which is located in the Lazio Region, central Italy (see: Fig. 1). The watershed outlet, which is ungauged, was selected at the confluence with the Tiber River, determining a total contributing area equal to $168.1 \mathrm{~km}^{2}$. Elevations range from $63 \mathrm{~m}$ to $1052 \mathrm{~m}$, while the average basin slope is around $10 \%$. The basin DEM was derived, thanks to the Italian Geographic Military Institute (IGMI, 2003), by the interpolation of 1:25.000 contour lines reported in the raster dataset. The analyzed DEM is characterized by a $20 \mathrm{~m}$ spatial resolution and by a spatial and vertical accuracy of 5-10 $\mathrm{m}$ and $1-5 \mathrm{~m}$, respectively. It is noteworthy that the IGMI DEM was chosen since it represents the official topographic data source used by Italian River Basin Authorities when dealing with flood mapping procedures. Land cover was graciously provided by the CORINE project $(\mathrm{Eu}-$ ropean Commission, 2000).

Rainfall data, consisting of 71 years (from 1928 to 2015 , with gaps) of annual maxima observations for durations of $1,3,6,12$, and 24 hours, plus 22 additional years (from 1994 to 2015) at high resolution (from 1 minute to 15 minutes) were retrieved from the nearest rain gauge station, in the Viterbo City. Indeed, annual maxima of cumulative rainfall data characterized by the durations of $1,3,6,12$, and 24 hours constitute the national standard data provided each year by the Italian River Basin Authorities to the hydrological community.

Daily and hourly rainfall observations occurring from 1994 to 2015 were used as input of the HyetosR 1.1 software (Koutsoyiannis and Onof, 2001), designed for the temporal stochastic simulation of
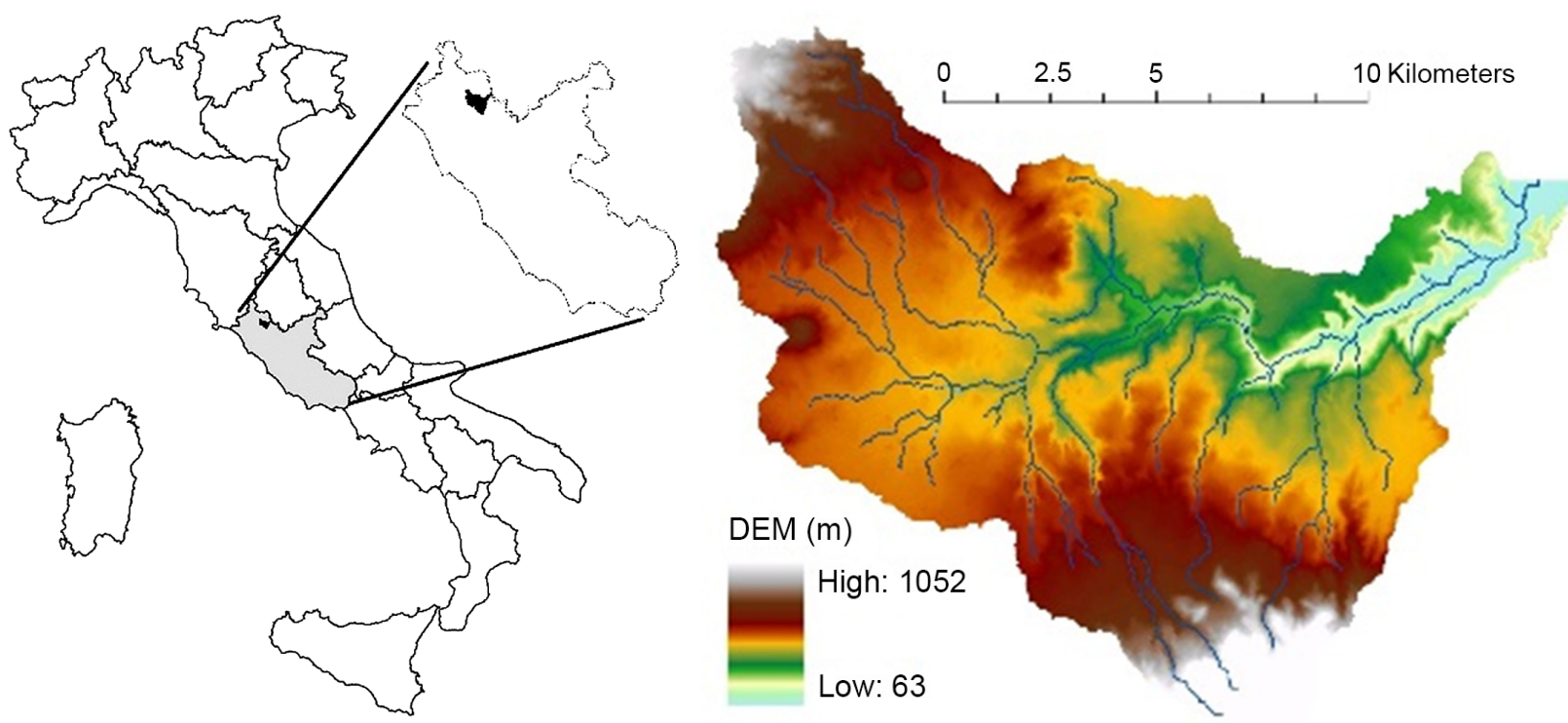

Fig. 1. Vezza river basin case study. Localization (Italy and Lazio region, in grey, left), DEM and drainage network (right) 
the rainfall process at fine time scale (sub-daily). HyetosR 1.1 software uses the Bartlett-Lewis rectangular pulses rainfall model (Onof and Wheater, 1993,1994), and disaggregation techniques that adjust the finer scale values in order to obtain the required coarser scale values without affecting the stochastic structure of the data (Koutsoyiannis, 2001). The model was calibrated on the observed rainfall data, preserving the mean, variance, auto covariance and proportion of dry and wet periods for both daily and hourly data (Grimaldi et al., 2016). Data was then used to generate a synthetic rainfall time series of 500 years at 1-hour resolution. Such synthetic rainfall time series represents the input data for the event-based and the continuous modeling approaches adopted in this study, as explained below.

\section{Event-based modeling approach - EBA4SUB framework}

The 500 years synthetic rainfall time series obtained using HyetosR 1.1 was analyzed extracting the 500 annual maxima of cumulative values with the standard durations of $1,3,6,12$, and 24 hours. Such values allowed the calculation of the DDF curves that were based on the empirical Weibull formulation for return periods $\mathrm{T}_{\mathrm{r}}$ equal to $10,20,50$ and 100 years, according to the following:

$$
\frac{j}{n+1}=1-\frac{1}{T_{r}}
$$

Where $j=1, \ldots, \mathrm{n}$ denotes the $j^{\text {th }}$ observation of the samples arranged in ascending order and characterized by the return period $T_{r}$. The empirical Weibull formulation was selected for its simplicity and because it is widely used in hydrological applications (Alfieri et al. 2008; Grimaldi et al. 2012a). Moreover, we generate a 500 years synthetic rainfall time series and we analyze return periods up to 100 years; therefore, we do not have to extrapolate design values for periods greater than the time series length. This leads us to approximate the probability by an empirical distribution rather than a parametric one. The common two-parameters (a and $n$ ) DDF curve has been selected as functional shape for expressing the design gross rainfall as follows:

$$
P=a t^{n}
$$

Where $\mathrm{P}$ is the cumulative gross rainfall value $(\mathrm{mm})$, $\mathrm{t}$ the rainfall duration $(\mathrm{h}), \mathrm{a}(\mathrm{mm} / \mathrm{h})$ and $\mathrm{n}$ (dimensionless) the curve parameters related to the return period. The DDF curves were used as input rainfall data for the Event-Based Approach For Small and Ungauged Basins (EBA4SUB) conceptual rainfall-runoff model (Grimaldi and Petroselli 2015, Piscopia et al. 2015, Petroselli and Grimaldi 2018). The framework consists of the following modules: A) design gross rainfall estimation and design hyetograph selection, B) excess rainfall estimation, and C) rainfall-runoff transformation.

In module A), EBA4SUB can use real precipitation events observed at rain gauges, or employ, like in the present work, the DDF curves, selecting different design rainfall patterns. In detail, the cumulative value for the design rainfall characterized by the investigated return period was estimated employing Eq. (2), assuming a rainfall duration equal to the time of concentration of the basin that was estimated equal to 8 hours using the Giandotti (1934) formula:

$$
T_{c}=\frac{1.5 L+\sqrt{A}}{0.8 \sqrt{H}}
$$

Where $T_{c}$ is the time of concentration of the catchment, $A$ is the catchment area $\left(\mathrm{km}^{2}\right), \mathrm{L}$ is the length of the main river $(\mathrm{km})$, and $H$ is the difference between the catchment average elevation and the outlet elevation $(\mathrm{m})$.

The areal reduction factor (ARF) has been applied according to Leclerc and Schaake (1972) to account for reduction due to spatially extended rainfall variability. Finally, the rectangular, symmetric triangular and symmetric Chicago hyetographs were selected for the estimation of the design gross rainfall hyetograph (Alfieri et al. 2008).

In module B), for each of the considered design gross rainfall hyetographs, the excess rainfall estimation was performed applying the SCS-Curve Number method (NRCS 2008). We are aware that the SCS-CN method has its limitations. For instance, it is restricted to certain geographic regions and land use types, it does not describe the spatial variability of runoff, and it is definitely not an infiltration equation, so its use is not appropriate for estimating the incremental rainfall excess at finer timescales during a storm event (Garen and Moore, 2005; Eli and Lamont, 2010). However, it is one of the most used abstraction models world- 
wide (Ponce and Hawkins, 1996). In the years, several modifications and improvements of the method have been developed (Geetha et al., 2007; Durbude et al., 2011; Bartlett et al., 2016a,b; Read and Vogel, 2015; Ogden, 2017), but in the present study we refer to the original formulation for simplicity. The Curve Number $(\mathrm{CN})$ value, as a weighted average for the whole basin considering the specific land cover and soil type, was automatically estimated by EBA4SUB. Additional hypotheses had an initial abstraction ratio assumed to be equal to 0.2 , as suggested in the original formulation, and a Hydrologic Soil Group equal to $\mathrm{B}$, selected based on available soil data. The $\mathrm{CN}$ estimation was performed, using look-up tables that link CN with land cover / soil type, both in Antecedent Moisture Condition (AMC) II (average condition for soil moisture; CN 68.1) and in AMC III (wet soil; CN 82.9). EBA4SUB estimates the excess rainfall employing the CN4GA (Grimaldi et al., 2013a,b) module, that combines the SCS-Curve Number method with the Green-Ampt (1911) infiltration scheme. However, in this specific analysis, in order to reduce the computational time of the continuous modeling, we preferred to use the classical SCS-CN method.

In module $\mathrm{C}$ ), the rainfall-runoff transformation was performed using the width function-based instantaneous unit hydrograph (WFIUH-1par) (Grimaldi et al., 2012). WFIUH-1par calculates the time distribution of the concentration of all DEM cells to the outlet estimating the surface flow velocity both in river network cells and in hillslope cells:

$$
\operatorname{WFIUH}(t)=\frac{L_{c}(x)}{v_{c}(x)}+\frac{L_{h}(x)}{v_{h}(x)}
$$

where $L_{c}(\mathrm{~m})$ and $L_{h}(\mathrm{~m})$ are the drainage path in the channel and along the hillslope, respectively, and are related to the DEM cell $\mathrm{x}$ of the watershed. The parameters $v_{c}\left(\mathrm{~m} \cdot \mathrm{s}^{-1}\right)$ and $v_{h}\left(\mathrm{~m} \cdot \mathrm{s}^{-1}\right)$ are the velocity values in the channel and along the hillslope. The WFIUH is estimated as in the following. First, the DEM is preprocessed to remove spurious points such as pits and flat areas (Petroselli and Fernandez Alvarez, 2012). Second, hillslope cell velocities are calculated employing a formula linking the hillslope velocity to local slope and land cover (Grimaldi et al., 2010). Third, river network cell velocity is calibrated by the model assuring that the center of the WFI-
UH mass is equal to the basin lag time $\left(T_{L}\right) \cdot T_{L}$ is estimated proportionally to the time of concentration $\left(T_{c}\right)$ according to the relation $T_{L}=0.6 T_{c}$ (Chow et al. 2008). After having defined the WFIUH, the runoff hydrograph $q(t)\left(\mathrm{m}^{3} \cdot \mathrm{s}^{-1}\right)$ is described by the following equation:

$$
q(t)=A \int_{0}^{t} W F I U H(t-\tau) \cdot \operatorname{Pn}(\tau) d \tau
$$

where A is the catchment area $\left(\mathrm{km}^{2}\right), \mathrm{t}$ the time $(\mathrm{h}), \tau$ a dummy variable $(h), \operatorname{Pn}(\tau)$ the height of previously determined excess rainfall $(\mathrm{mm} / \mathrm{h})$. The analysis was conducted at 1-hour time resolution and allowed the DH estimation, with the corresponding peak discharge, for the specified return periods.

\section{Continuous modeling approach - COSM04SUB framework}

The 500 years synthetic rainfall time series at 1 hour resolution obtained using HyetosR 1.1 was used as input data of the simulation framework named COSMO4SUB (COntinuous Simulation MOdel For Small and Ungauged Basins). COSMO4SUB (Grimaldi et al., 2012a,b) consists of a multistep procedure characterized by a rainfall generator, an infiltration and rainfall excess model, and a rainfall-runoff model.

Regarding the second step, the excess rainfall estimation was performed applying again the SCS-Curve Number method (NRCS 2008), by automatically changing the AMC condition based on the cumulative value of rainfall occurred in the previous 5 days with COSMO4SUB. It is important to note that the continuous implementation of the SCS-CN method requires an additional parameter called the event separation time. This represents the no-rain time interval that separates two sequential events that can be considered independent in terms of initial infiltration conditions. In this work, the event separation time was assumed equal to 24 hours, following Grimaldi et al. (2012a,b). Moreover, AMC selection was performed according to the official NRCS (2008) formulation, evaluating the cumulative rainfall in the 5 days before the generic rainfall event (P5d) and considering the vegetation growing season (assumed from May to November) or dormant season (assumed from December to April). AMC I (dry condition of soil) was defined for P5d lower than $12.7 \mathrm{~mm}$ (dormant season) or lower than 
$35.6 \mathrm{~mm}$ (growing season). AMC II (normal or average condition) was defined for P5d ranging between $12.7 \mathrm{~mm}$ and $27.9 \mathrm{~mm}$ (dormant season) or ranging between $35.6 \mathrm{~mm}$ and $53.3 \mathrm{~mm}$ (growing season). AMC III (wet condition for soil) was defined for P5d higher than $27.9 \mathrm{~mm}$ (dormant season) or higher than $53.3 \mathrm{~mm}$ (growing season).

Regarding the third step, the same WFIUH-1par of the event-based modeling approach was used. The analysis was performed, as for the event-based approach, at 1-hour timescale. At the end of the COSMO4SUB simulation, 500 years of continuous runoff at 1-hour time resolution were available. From the resulting runoff time series, 500 annual maxima of peak discharge were selected and their return period was estimated applying the empirical Weibull formulation (Eq. 1) for 10, 20, 50 and 100 years.

\section{RESULTS AND DISCUSSION}

The DDF curves obtained analyzing the 500 years synthetic rainfall time series are shown in Figure 2. The design peak discharges $\left(Q_{p}\right)$ computed from both approaches are reported and shown in Table 1 and Figure 3 . The percentage differences between the continuous modeling, assumed as reference, and the investigated event-based approaches are reported in Table 2. Differences in peak discharges between the two modeling approaches are evident.
A first comment concerns the obtained wide range given by the EBA4SUB implementations for each return period and the assumed AMC conditions. The wide variability decreases by increasing the return period. For instance, considering the rectangular hyetograph, for $T_{r} 10$ years, $Q_{p}$ ranges from $66.4 \mathrm{~m}^{3} \cdot \mathrm{s}^{-1}$ (AMC II) to $170.4 \mathrm{~m}^{3} \cdot \mathrm{s}^{-1}$ (AMC III), with an increase of $256 \%$, while for $T_{r} 100$ years $Q_{p}$ ranges from $177 \mathrm{~m}^{3} \cdot \mathrm{s}^{-1}$ (AMC II) to $324.8 \mathrm{~m}^{3} \cdot \mathrm{s}^{-1}$ (AMC III), with an increase of $183 \%$. A similar behavior is confirmed also with the Chicago hyetograph and with the triangular hyetograph.

These results highlight the critical role of AMC and how subjective the event-based approach is for determining the design hydrograph and peak discharge. Indeed, it is well known in the literature that flood generation is strongly influenced by soil moisture at the moment of rainfall. For instance, Papaioannou et al. (2018) state that "the uncertainty induced in hydrological modelling, in particular concerning the antecedent soil moisture conditions, requires to move to more rigorous (stochastic) methodological approaches, instead of quantifying the flood risk on the basis of the return period of rainfall".

A second comment concerns the range of peak discharge obtained considering different rainfall patterns in the event-based approach for the selected AMC. The Chicago hyetograph always yields greater values of peak discharge than the triangular or rectangular

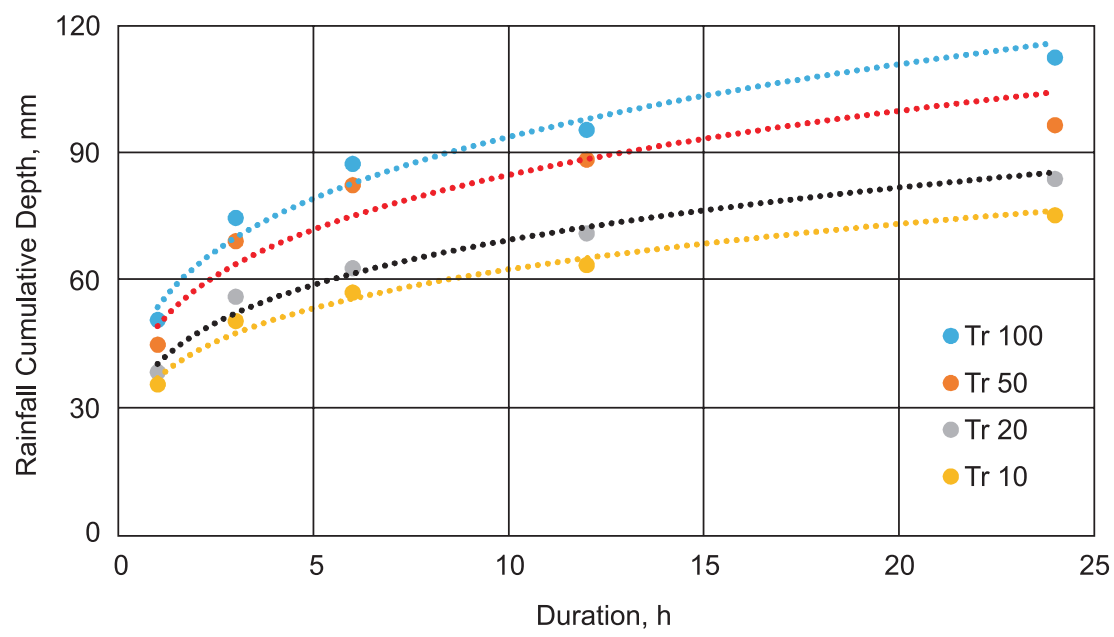

Fig. 2. The DDF curves obtained with the empirical Weibull formulation on the 500 years synthetic rainfall time series 
hyetographs, which always restitute lower values for peak discharge. Such difference increases with $T_{r}$. For instance, for AMC II, the percentage difference between the peak discharges obtained with the Chicago hyetograph and with the rectangular one is equal to $9.4 \%$ for $T_{r}=10$ years, while it increases up to $14 \%$ for $T_{r}=100$ years. The same percentage differences, in case of AMC III, are $18.5 \%$ and $22.2 \%$ respectively, thus highlighting the importance of selecting a specific temporal rainfall distribution.

Such behavior is in line with recent literature. For instance, Wałęga (2016) reported that the hyetograph shape impacted up to $20 \%$ of the differences in peak discharges, while Oliveira and Stolpa (2003) determined that gross rainfall rectangular distribution with duration equal to the catchment time of concentration generates significantly lower peak flows compared to other hyetograph shapes. As it can be seen from the obtained results, both AMC selection and gross rainfall pattern selection determine a notable uncertainty in peak discharge values estimated with the eventbased approach. However, the uncertainty inherent in the estimation of the soil moisture antecedent to rainfall appears to be predominant.

Conversely, it is true that the continuous modeling approach is able to automatically adjust AMCs based on rainfall data. Regarding the results obtained with
COSMO4SUB, it is interesting to note that $Q_{p}$ values are positioned inside the range of values provided by EBA4SUB with AMC II and with AMC III. Indeed, for any $T_{r}$ and for any selected gross rainfall pattern, COSMO4SUB $Q_{p}$ values are much lower than the corresponding ones obtained with EBA4SUB - AMC III, and are slightly larger than the ones obtained with EBA4SUB - AMC II. For instance, for $T_{r} 10$ years, COSMO4SUB $Q_{p}$ values are $20 \%-28 \%$ higher than EBA4SUB - AMC II, and 85\%-125\% lower than EBA4SUB - AMC III. Again, the percentage differences decrease with increasing $T_{r}$. For $T_{r} 100$ years, COSMO4SUB $Q_{p}$ values are $7 \%-20 \%$ higher than EBA4SUB - AMC II, and 47\%-89\% lower than EBA4SUB - AMC III.

From an engineering point of view, it seems that simultaneously assuming an AMC III condition and a rainfall duration equal to the basin time of concentration produces an unrealistic scenario, which represents the upper threshold for design peak discharge, for any return period. On the contrary, a combination of AMC II and critical rainfall duration seems to be more realistic, as reproduced by the COSMO4SUB $Q_{p}$ values. Looking at Figure 3, we can synthetically state that there is a certain similarity between the peak discharge values estimated with the event-based approach in AMC II condition (for all the investigated gross rain-

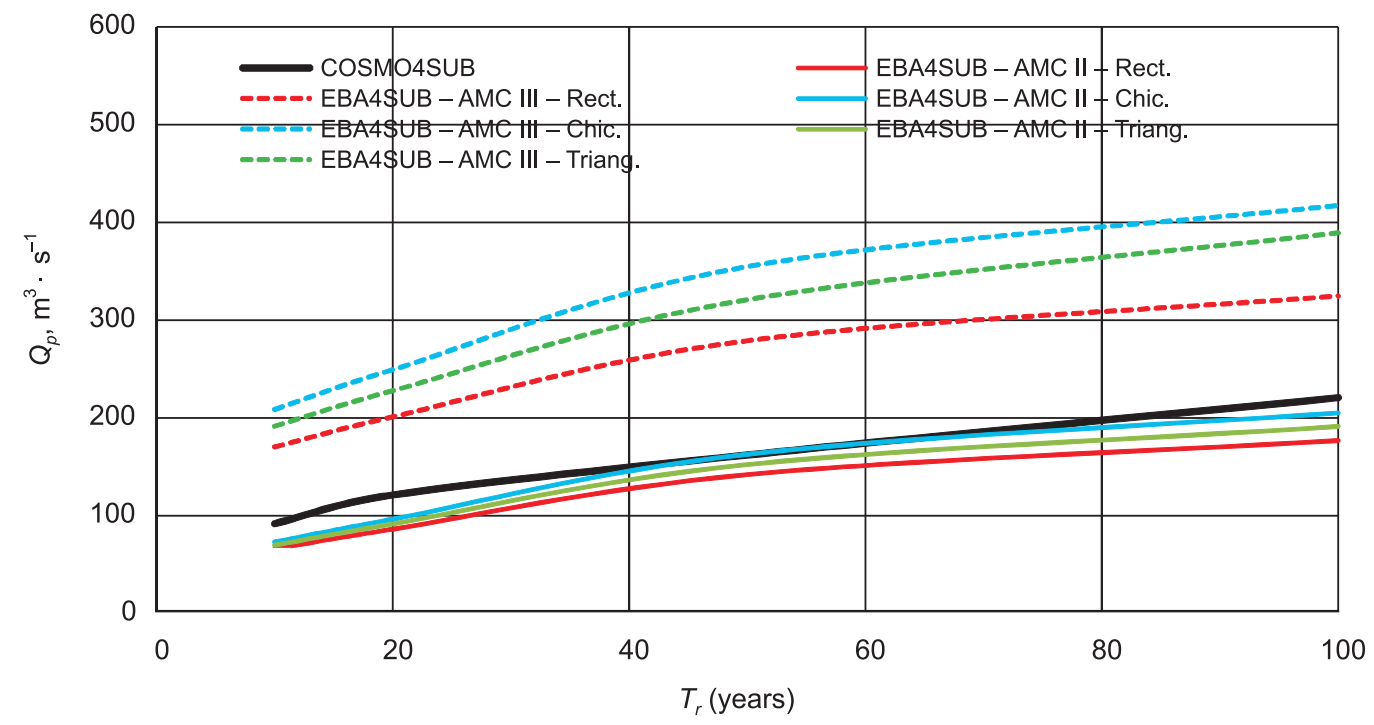

Fig. 3. Relationship between design peak discharge and return period for the investigated approaches 
Table 1. The obtained design peak discharge values

Design peak discharge, $\mathrm{m}^{3} \cdot \mathrm{s}^{-1}$

\begin{tabular}{lcccc}
\hline $\operatorname{Tr}(\mathrm{y})$ & 10 & 20 & 50 & 100 \\
\hline COSMO4SUB & 92.07 & 121.42 & 162.33 & 220.89 \\
\hline EBA4SUB - AMC II - Rect. Hyet. & 66.39 & 86.45 & 142.22 & 177.04 \\
\hline EBA4SUB - AMC II - Triang. Hyet. & 70.03 & 91.82 & 152.50 & 191.45 \\
\hline EBA4SUB - AMC II - Chic. Hyet. & 73.32 & 96.72 & 162.97 & 205.39 \\
\hline EBA4SUB - AMC III - Rect. Hyet. & 170.39 & 201.20 & 279.04 & 324.80 \\
\hline EBA4SUB - AMC III - Triang. Hyet. & 191.67 & 228.03 & 321.06 & 389.33 \\
\hline EBA4SUB - AMC III - Chic. Hyet. & 209.01 & 249.55 & 354.92 & 417.32 \\
\hline
\end{tabular}

Table 2. Percentage differences between peak discharge estimated with COSMO4SUB and with the event-based approaches differences (\%) between COSMO4SUB respect to:

\begin{tabular}{lcccc}
\hline $\operatorname{Tr}(\mathrm{y})$ & 10 & 20 & 50 & 100 \\
\hline EBA4SUB - AMC II - Rect. Hyet. & 27.9 & 28.8 & 12.4 & 19.9 \\
\hline EBA4SUB - AMC II - Triang. Hyet. & 23.9 & 24.4 & 6.1 & 13.3 \\
\hline EBA4SUB - AMC II - Chic. Hyet. & 20.4 & 20.3 & -0.4 & 7.0 \\
\hline EBA4SUB - AMC III - Rect. Hyet. & -85.1 & -65.7 & -71.9 & -47.0 \\
\hline EBA4SUB - AMC III - Triang. Hyet. & -108.2 & -87.8 & -97.8 & -76.3 \\
\hline EBA4SUB - AMC III - Chic. Hyet. & -127.0 & -105.5 & -118.6 & -88.9 \\
\hline
\end{tabular}

fall hyetographs) and the peak discharge values provided by the continuous modeling approach. In such circumstances, in our opinion, the continuous modeling approach should be preferred because it favors safety and because it minimizes the user subjectivity. Namely, with the continuous modeling approach, the choice of AMC, of the hyetograph shape, and of the rainfall duration can be avoided. Conversely, it seems that if the event-based approach in AMC III condition is employed, the estimated peak discharges appear overestimated. This is particularly true with a gross rainfall distribution characterized by non-constant rainfall intensity, like the Chicago hyetograph. In fact, by definition, the Chicago hyetograph is the upper limit of rainfall depth since it represents the critical rainfall for all partial durations of the event. The effect of the combined selection of the Chicago hyetograph and AMC III leads to the limiting peak discharges in the worst speculated conditions.

Our results seem to confirm findings found in the literature. For instance, Grimaldi et al. (2012b) compared the continuous modeling approach with eventbased approaches applied with AMC II and different rainfall patterns: they concluded that estimations from the continuous modeling approach are generally greater than from event-based approaches, with differences, for $T_{r} 100$ years, approximately of $20 \%$ and $40 \%$, when considering Chicago and rectangular hyetograph, respectively. Also, the differences between $Q_{p}$ obtained with the two approaches decrease with the increase in $T_{r}$. Moreover, Grimaldi et al. (2013c) analyzed the flood maps determined with both ap- 
proaches, determining an average difference of $34 \%$ between $Q_{p}$ values, with the continuous modeling approach values again being higher than the event-based approach. The authors concluded that inundation mapping based on a design hydrograph, using event-based approach, should be used with caution since the flood volume, which can be for instance estimated employing empirical formula based on the peak discharge, may be significantly underestimated. Finally, Winter et al (2019) determined that $Q_{p}$ values obtained with the continuous modeling approach were systematically higher than with event-based approaches, with differences up to approximately $40 \%$ for $T_{r} 100$ years. In their paper, the authors argued that the event-based approach results could not fully account for the variability of possible flood events, which can possibly lead to sensibly lower runoff volumes. Therefore, the use of the event-based approach may lead to an underestimation of peak discharge in comparison to the continuous modeling approach, and this is particularly important in applications like flood mapping since the potential damage is influenced by both flood peak and runoff volume.

\section{SUMMARY AND CONCLUSIONS}

In this contribution, the benefit of continuous modeling compared to the event-based approach for the estimation of the design peak discharge for small and ungauged basins is illustrated. Two recently developed methodologies, both characterized by state-of-the-art modules, were adopted. EBA4SUB is a typical eventbased approach consisting in a series of modules such as design gross rainfall estimation, excess rainfall estimation, and rainfall-runoff transformation. COSMO4SUB is a continuous simulation framework that employs a long synthetic rainfall time series and produces the corresponding runoff time series that can be analyzed statistically, in order to derive annual maxima of computed peak discharge. The case study demonstrated the relevant role of the Antecedent Moisture Condition (AMC) on the estimated results. Notably, in the event-based approach, AMC is arbitrarily selected by the analyst, while in the continuous modeling it is automatically determined using the synthetic rainfall input. Our findings indicate that the event-based approach systematically leads to an overestimation of floods if AMC III is assumed (up to approximately $90 \%$ for $T_{r} 100$ years, Chicago hyetograph) or to an underestimation of floods if AMC II is selected (down to approximately $20 \%$ for $T_{r} 100$ years, rectangular hyetograph).

This is only one among the numerous additional benefits of the continuous framework. In fact, its application allows avoiding several modeling choices present in the event-based approach, including the selection of the hyetograph shape and the critical rainfall duration assumption. This work confirms that the major drawback of the event-based approach is due to the high level of subjectivity of this procedure (in particular the estimation of the AMC) that significantly affects results.

\section{REFERENCES}

Alfieri, L., Laio, F., Claps, P. (2008). A simulation experiment for optimal design hyetograph selection. Hydrological Processes 22, 813-820.

Bartlett, M.S., Parolari, A.J., McDonnell, J.J., Porporato, A. (2016a). Beyond the SCS-CN method: A theoretical framework for spatially lumped rainfall-runoff response. Water Resour. Res., 52, DOI:10.1002/ 2015WR018439.

Bartlett, M.S., Parolari, A.J., McDonnell, J.J., Porporato, A. (2016b). Framework for event-based semidistributed modeling that unifies the SCS-CN method, VIC, PDM, and TOPMODEL. Water Resour. Res., 52, DOI:10.1002/2016WR019084.

Chow, V.T., Maidment, D.R., Mays, L.W. (1988). Applied hydrology. New York: McGraw Hill.

Di Baldassarre, G., Castellarin, A., Montanari, A., Brath, A. (2009). Probability weighted hazard maps for comparing different flood risk management strategies: a case study. Nat. Hazards 50 (3), 479-496.

Directive 2007/60/EC. 2007. Of the European Parliament and of the Council of 23 October 2007 on the assessment and management of flood risk. Official Journal of the European Union L288, 27-34.

Dooge, J.C.I. (1973). Linear theory of hydrologic systems. Technical Bulletin 1468. United States Department of Agriculture.

Durbude, D.G., Jain, M.K., Mishra, S.K. (2011). Long-term hydrologic simulation using SCS-CN-based improved soil moisture accounting procedure. Hydrological Processes 25(4), 561-579.

Eli, R.N, Lamont, S.J. (2010). Curve numbers and urban runoff modeling - application limitations. Low Impact 
Development 2010: Redefining Water in the City, Proceedings of the 2010 International Low Impact Development Conference, 405-418.

European Commission. (2000). CORINE (Coordination of Information on Environment) Database, a Key Database for European Integrated Environmental Assessment. Programme of the European Commission, European Environmental Agency (EEA).

FEMA. (2009). Guidelines and Specifications for Flood Hazard Mapping Partners, Appendix C: Guidance for Riverine Flooding Analyses and Mapping. http://www. fema.gov/library/viewRecord.do?id=

Garen, D.C, Moore, D.S. (2005). Curve number hydrology in water quality modeling: uses, abuses, and future directions. Journal of the American Water Resources Association, 41(2), 377-388.

Geetha, K., Mishra, S.K., Eldho, T.I., Rastogi, A.K., Pandey, R.P. (2007). Modifications to SCS-CN method for longterm hydrologic simulation. Journal of Irrigation and Drainage Engineering, 133(5), 475-486.

Giandotti, M. (1934). Previsione delle piene e delle magre dei corsi d'acqua (Estimation of floods and droughts of rivers). Istituto Poligrafico dello Stato, 8, 107-117. In Italian.

Green, W.H., Ampt, G.A. (1911). Studies on soil physics. J. Agric. Sci. 4, 1-24.

Grimaldi, S., Petroselli, A., Nardi, F., Alonso G. (2010). Flow time estimation with variable hillslope velocity in ungauged basins. Adv. Water Resour. 33, 1216-23.

Grimaldi S., Petroselli A., Serinaldi F. (2012a). A continuous simulation model for design hydrograph estimation in ungauged watersheds. Hydrological Sciences Journal, 57(6), 1035-1051.

Grimaldi, S., Petroselli, A., Serinaldi, F. (2012b). Design hydrograph estimation in small and ungauged watersheds: continuous simulation method versus event-based approach. Hydrol Process, 26(20), 3124-34.

Grimaldi, S., Petroselli, A., Romano, N. (2013a). GreenAmpt Curve Number mixed procedure as an empirical tool for rainfall-runoff modelling in small and ungauged basins. Hydrological Processes, 27(8), 1253-1264.

Grimaldi, S., Petroselli, A., Romano, N. (2013b). Curve-Number/Green-Ampt mixed procedure for streamflow predictions in ungauged basins: parameter sensitivity analysis. Hydrological Processes, 27(8), 1265-1275.

Grimaldi, S., Petroselli A., Arcangeletti, E., Nardi F. (2013c). Flood mapping in ungauged basins using fully continuous hydrologic-hydraulic modeling. Journal of Hydrology, 487, 39-47.

Grimaldi, S., Petroselli, A. (2015). Do we still need the rational formula? An alternative empirical procedure for peak discharge estimation in small and ungauged basins, Hydrol. Sci. J., 60, 66-7.

Grimaldi, S., Petroselli, A., Salvadori, G., De Michele, C. (2016). Catchment compatibility via copulas: a non-parametric study of the dependence structures of hydrological responses. Advances in Water Resources, 90, 116-133.

Hsieh, L.S., Hsu, M.H., Li, M.H. (2006). An assessment of structural measures for flood-prone lowlands with high population density along the Keelung River in Taiwan. Natural Hazards, 37(1-2), 133-152.

Hoes, O, Nelen, F. (2005). Continuous simulation or eventbased modelling to estimate flood probabilities? In Water Resources Management III, WIT transactions on ecology and the environment, vol. 80, de Conceicao Cunha M, Brebbia CA (eds). WIT press: Southampton, UK; 3-10.2206.

IGMI (Italian Geographic Military Institute). (2003). Raster (Matrix) Numerical DEM of Italy (Internal Factsheet, in Italian). http://www.igmi.org/pdf/info_matrix2003.pdf.

Kalyanapu, A., Judi, D., McPherson, T., Burian, S. (2012). Monte Carlo-based flood modelling framework for estimating probability weighted flood risk. J. Flood Risk Manage. 5, 37-48.

Koutsoyiannis, D., Onof, C. (2001) Rainfall disaggregation using adjusting procedures on a Poisson cluster model. J Hydrol. 246, 109-22.

Leclerc, G., Schaake, J.C. (1972). Derivation of hydrologic frequency curves. Report 142. Mass. Inst. of Technol., Cambridge, MA, USA.

Merwade, V., Olivera, F., Arabi, M., Edleman, S. (2008). Uncertainty in flood inundation mapping: current issues and future directions. J. Hydrol. Eng., 13(7), 608-620.

Moretti, G., Montanari, M. (2008). Inferring the flood frequency distribution for an ungauged basin using a spatially distributed rainfall-runoff model. Hydrology and Earth System Sciences, 12, 1141-1152.

Nishat, S, Guo, Y, Baetz, B.W. (2010). Antecedent soil moisture conditions of different soil types in South-western Ontario, Canada. Hydrological Processes, 24, 2417-2424 .

Nnadi, F.N., Kline, F.X., Wary, H.L., Wanielista, MP. (1999). Comparison of design storm concepts using continuous simulation with short duration storms. Journal of the American Water Resources Association, 31(1), 61-85.

NRCS (Natural Resources Conservation Service). (2008). National engineering handbook - part 630, Hydrology. U.S. Department of Agriculture, Washington, DC, USA. Ogden, F. L., Hawkins R.P., Walter M.T., Goodrich D.C. (2017). Comment on "Beyond the SCS-CN method: 
Atheoretical framework for spatially lumped rainfall-runoff response" by M. S. Bartlett et al., Water Resour. Res., 53, 6345-6350, DOI:10.1002/2016WR020176.

Onof, C., Wheater, H.S. (1993) Modelling of British rainfall using a Random Parameter Bartlett-Lewis Rectangular Pulse Model. J Hydrol.149, 67-95.

Onof, C., Wheater, H.S. (1994) Improvements to the modelling of British rainfall using a Random Parameter Bartlett-Lewis rectangular pulse model. J Hydrol.157, $177-95$.

Oliveira, F., Stolpa, D. (2003). Effect of the storm hyetograph duration and shape on the watershed response. In: Proceedings of the 82nd Annual Meeting of the Transportation Research Board, Washington, USA.

Papaioannou, G., Efstratiadis, A., Vasiliades, L., Loukas, A., Papalexiou, S. M., Koukouvinos, A., Tsoukalas, I., Kossieris, P. (2018). An operational method for Floods Directive implementation in ungauged urban areas. Hydrology 5 (2), 24.

Petroselli, A., Fernandez Alvarez, A. (2012). The flat area issue in DEMs and its consequences on the rainfall-runoff modelling. GIScience \& Remote Sensing, 49(5), 711-734.

Petroselli, A., Grimaldi, S. (2018). Design hydrograph estimation in small and fully ungauged basin: a preliminary assessment of the EBA4SUB framework. J. flood risk assessment. 11, 197-210.
Piscopia, R., Petroselli, A., Grimaldi S. (2015). A software package for the prediction of design flood hydrograph in small and ungauged basins, Journal of Agricultural Engineering, XLVI, 432, 74-84.

Ponce, V.M, Hawkins R.H. (1996). Runoff Curve Number: has it reached maturity? Journal of Hydrologic Engineering 1(1), 11-19.

Read, L.K., Vogel R.M. (2015). Reliability, return periods, and risk under nonstationarity. Water Resour. Res., 51, DOI:10.1002/2015WR017089.

Verhoest, NEC, Vandenberghe, S, Cabus, P, Onof, C, Meca-Figueras, T, Jameleddine S. (2010). Are stochastic point rainfall models able to preserve extreme flood statistics? Hydrological Processes, 24, 3439-3445.

Viglione, A, Blosch, l G. (2009). On the role of storm duration in the mapping of rainfall to flood return periods. Hydrology and Earth System Sciences, 13, 205-216.

Wałega, A. (2016). The importance of calibration parameters on the accuracy of the floods description in the Snyder's model. Journal of Water and Land Development, 28, 19-25.

Winter, B., Schneeberger, K., Dung, N.V., Huttenlau M., Achleitner S., Stötter, J., Merz, B., Vorogushyn, S. (2019). A continuous modelling approach for design flood estimation on sub-daily time scale. Hydrological Sciences Journal, 64(5), 539-554.

\section{EWALUACJA HYDROGRAFÓW KONCEPCYJNYCH W MAŁYCH ZLEWNIACH NIEWYPOSAŻONYCH W STACJE POMIAROWE: OCENA PORÓWNAWCZA PODEJŚCIA BAZUJĄCEGO NA ZDARZENIACH (EBA4SUB) Z METODĄ MODELOWANIA CIĄGŁEGO (COSMO4SUB)}

\section{ABSTRAKT}

\section{Cel pracy}

Praca ma na celu stworzenie oceny porównawczej podejścia bazującego na zdarzeniach (EBA4SUB) z metodą modelowania ciągłego (COSMO4SUB) używanych do tworzenia modelu opad-odpływ w małych zlewniach niewyposażonych w stacje pomiarowe, ze szczególnym uwzględnieniem wpływu uwilgotnienia gleby przed wystapieniem opadów (ang. Antecedent Moisture Condition, AMC) podczas przewidywanego spływu szczytowego.

\section{Materiały i metody}

Oprogramowanie EBA4SUB korzysta z podejścia bazującego na zdarzeniach. Wprowadza się do niego dane dotyczące zdarzenia opadowego i szacowanej skali opadu w celu wygenerowania bezpośredniego wykresu hydrograficznego. Model COSMO4SUB korzysta z podejścia ciagłego. Model generuje dane na podstawie szeregów czasowych długotrwałych syntetycznych opadów deszczu o częstotliwości wyższej niż codzienna. Dane te są wykorzystywane w modelu opad-odpływ. Następnie określa się szeregi czasowe spływu, co pozwala na oszacowanie odpływu i powiązanego spływu szczytowego. 


\section{Wyniki i wnioski}

Wyniki świadczą o kluczowej roli uwilgotnienia gleby przed wystapieniem opadów (AMC) oraz o tendencyjności podejścia bazującego na zdarzeniach podczas określania koncepcyjnych hydrografów oraz spływu szczytowego. Podczas stosowania podejścia bazującego na zdarzeniach analityk arbitralnie wybiera AMC, natomiast w przypadku podejścia bazującego na modelowaniu ciąłym, AMC jest określane automatycznie przy użyciu danych dotyczących opadów syntetycznych. Z badania wynika, że podejście bazujące na zdarzeniach prowadzi do regularnego i znacznego przeszacowywania skali powodzi, gdy zakłada się, że AMC jest na poziomie III (gleba wilgotna) oraz do nieznacznego niedoszacowywania skali powodzi, gdy zakłada się, że AMC jest na poziomie II (gleba średnio wilgotna).

Słowa kluczowe: modelowanie ciagłe, COSMO4SUB, hydrograf koncepcyjny, EBA4SUB, podejście bazujące na zdarzeniach, modelowanie opad-odpływ 